\title{
ARE LEGAL RULES CONTENT-INDEPENDENT REASONS?
}

\author{
Noam GUR*
}

RESUMEN:

En este artículo se argumenta que la respuesta a la pregunta de si las normas jurídicas son razones "independientes de contenido" depende de tres distinciones que demarcan cómo las normas jurídicas son razones independientes de contenido en algunos sentidos, pero no en otros. La primera distinción es entre dos sentidos de "independiente de contenido" que el autor refiere como fuerte y débil. En el argumento se sostiene que, si bien las normas jurídicas generan razones independientes de contenido en el sentido débil, el hecho de que generen razones independientes de contenido en el sentido fuerte depende, a su vez, de otras dos distinciones: primero, una distinción entre enunciados evaluativos y descriptivos de razones; y segundo, una distinción entre razones para la acción y razones para adoptar ciertas actitudes. La independencia de contenido fuerte - continúa el argumento- es una noción consistente sólo en la medida en que se formule con enunciados descriptivos de razones (a diferencia de enunciados evaluativos de razones) que se relacionan con acciones (en contraste con las actitudes). Finalmente, se enuncia una tesis implícita que vincula los diferentes sentidos en que las normas jurídicas son razones independientes de contenido, al mismo tiempo que explica sus diferencias.

* Shaw Foundation Fellow in Law, Lincoln College, Oxford. I am grateful for helpful comments and suggestions of the participants in this symposium, in a Legal Normativity workshop at the IVR Conference 2011, in a jurisprudence workshop at the SLS Annual Conference 2011, and in the Oxford Jurisprudence Discussion Group. I am also grateful to Fred Schauer for helpful comments on an earlier draft of this paper. 
NOAM GUR

Palabras clave:

Razones independientes de contenido, normas jurídicas, normatividad, H. L. A. Hart, Joseph Raz.

\section{ABSTRACT:}

I argue that the answer to the above question turns on three distinctions which make it clear that legal rules are content-independent reasons in some senses, but not in others. The first distinction is between two senses of content-independence, which I refer to as weak and strong content-independence. I argue that, while legal rules do give rise to content-independent reasons in the weak sense, whether they can be said to generate content-independent reasons in the strong sense depends on two further distinctions: first, a distinction between evaluative and descriptive statements about reasons; second, a distinction between reasons for action and reasons for adopting certain attitudes. Strong content-independence, I argue, is a sound notion only insofar as it figures in descriptive reason-statements (as opposed to evaluative reason-statements) with regard to actions (as opposed to attitudes). Finally, I uncover an underlying explanation that links the different senses in which legal rules are content-independent reasons, and accounts for the differences between them.

Keywords:

Content-Independent Reasons, Legal Rules, Normativity, H. L. A. Hart, Joseph Raz. 
ARE LEGAL RULES CONTENT-INDEPENDENT REASONS?

Summary: I. Introduction. II. Strong and Weak Content-Independence. III. Does Law Provide Weakly/Strongly Content-Independent Reasons? IV. A Discrepancy with Good Reason. V. Conclusion.

\section{INTRODUCTION}

Since introduced by H. L. A. Hart and espoused by Joseph Raz, content-independent reasons have become part and parcel of the conceptual vocabulary of legal theorists. ${ }^{1}$ Yet the range of reactions provoked by this notion manifests a serious dissonance in jurisprudential thought. On the one hand, several theorists have acknowledged that the notion successfully captures a key feature of law's normativity and authoritative nature. ${ }^{2}$ On the other hand, as one writer put it, "few believe I can have a reason to perform an action simply and only because the law to which I am subject says I must" 3 - a denial that appears intuitively plausible yet seems to stand in direct opposition to the idea of content-independence. In this paper, I argue that the key to resolving this dissonance lies in three distinctions: (1) a dis-

1 Hart, H. L. A., Essays on Bentham, Oxford, Clarendon Press, 1982, pp. 18, 243-68; Raz, Joseph, The Morality of Freedom, Oxford, Clarendon Press, 1986, pp. 35-7. See further Green, Leslie, The Authority of the State, Oxford, Clarendon Press, 1990, pp. 41-62, 225-6; Duff, R. A., "Inclusion and Exclusion", Current Legal Problems, vol. 51, 1998, pp. 241-66, at p. 247; Himma, Kenneth E., "Hart and the Practical Difference Thesis", Legal Theory, vol. 6, 2000, pp. 1-43, at pp. 26-7; Shapiro, Scott, "Authority", in Coleman, Jules L. and Shapiro, Scott (eds.), The Oxford Handbook of Jurisprudence and Philosophy of Law, Oxford, Oxford University Press, 2002, p. 389; Christiano, Thomas, "Authority", in Stanford Encyclopedia of Philosophy, <http://plato.stanford.edu/entries/authority/>, accessed 1 March 2011 (referring mostly to content-independent duties); Schauer, Frederick, "Authority and Authorities", Virginia Law Review, vol. 94, 2008, pp. 1931-61, at pp. 1935-6.

2 See, e.g., Green, supra note 1, pp. 41-62, 225-6; Schauer, supra note 1, pp. 1935-6; Christiano, supra note 1.

3 Markwick, Paul, "Independent of Content", Legal Theory, vol. 9, 2003, pp. 43-61, at p. 57; Markwick, Paul, "Law and Content-Independent Reasons", Oxford Journal of Legal Studies, vol. 20, 2000, pp. 579-96, at p. 586 (though this statement of Markwick is merely incidental to his main objections against content-independent reasons). See further Edmundson, William A., Three Anarchical Fallacies, Cambridge, Cambridge University Press, 1998, pp. 12-4. 
tinction between two understandings of content-independence, which I refer to as weak and strong contentindependence; (2) a distinction between evaluative statements about reasons and descriptive statements about reasons; and (3) a distinction between reasons for action and reasons for adopting certain attitudes. Drawing on these three distinctions, my analysis leads to a nuanced answer to the question of whether rules (and other requirements) of law provide content-independent reasons: in some senses they do, in others they do not. ${ }^{4}$ In the final part of the paper, I uncover an underlying rationale that connects and explains the disparity between the senses in which law does and does not provide content-independent reasons.

\section{Strong And Weak Content-IndePendence}

Let us begin with the relevant ambiguity in the notion of content-independence. Pertinent to my analysis are two possible renderings of content-independence: according to the first rendering, to say that the reasons law generates are content-independent is to say that their status as reasons does not depend on the question of what action a given legal provision requires, but rather is attributable to the fact that law requires the action. It will be noticed that this rendering consists of both a negative element (i.e. "does not depend on the question of what action a given legal provision requires") and a positive element (i.e. "is attributable to the fact that law requires the action"). This sense of content-independence, which will be referred to as the strong

4 Phrasing the question this way, i.e. asking whether rules provide (or generate, supply, give rise to, etc.) content-independent reasons, is analytically more correct than the formulation used in the title, i.e. whether rules are content-independent reasons, since the latter formulation is pleonastic: to say that rules are reasons is to say that they themselves (or the fact of their enactment) are reasons, rather than that their content happens to coincide with what we anyway have reasons to do. Thus, if rules are reasons they are, eo ipso, content-independent reasons. In light of this, I will be mostly using terms such as provide/generate/give rise to content-independent reasons, and even when using different terminology I should be taken to mean the same. 
ARE LEGAL RULES CONTENT-INDEPENDENT REASONS?

sense, appears to correspond with Hart's basic characterization of this notion, as follows:

Content-independence of commands lies in the fact that a commander may issue many different commands to the same or to different people and the actions commanded may have nothing in common, yet in the case of all of them the commander intends his expressions of intention to be taken as a reason for doing them. It is therefore intended to function as a reason independently of the nature or character of the actions to be done. ${ }^{5}$

Joseph Raz, at one juncture, provides a similar explanation of content-independence:

A reason is content-independent if there is no direct connection between the reason and the action for which it is a reason. The reason is the apparently 'extraneous' fact that someone in authority has said so, and within certain limits his saying so would be reason for any number of actions, including (in typical cases) for contradictory ones. A certain authority may command me to leave the room or to stay in it. Either way, its command will be a reason. This marks authoritative reasons as content-independent. ${ }^{6}$

It can be readily seen that these passages refer both to what I called the negative element (Hart: "independently of the nature or character of the actions to be done"; Raz: "no direct connection between the reason and the action for which it is a reason") and to what I called the positive element (Hart: "the commander intends his expressions of intention to be taken as a reason"; Raz: "[t]he reason is the apparently 'extraneous' fact that someone in authority has said so"7). Similar expressions of the strong sense of con-

5 Hart, supra note 1, p. 254.

6 Raz, supra note 1, p. 35.

7 This is not the only possible understanding of Raz's comment: it is conceivable that his words "someone in authority" are intended to mean "someone who meets the substantive prerequisites for being a legitimate authority", which im- 
tent-independence can be found in statements of several other legal theorists, such as Leslie Green's comment that "[t]he core idea [of content-independence] is that the fact that some action is legally required must itself count in the practical reasoning of citizens, independently of the nature and merits of that action", ${ }^{8}$ and Scott Shapiro's remark that "[o]ne who obeys a command treats the command as a content-independent reason, because he complies for the reason that he was commanded, not because he has reasons to act on the content of that command". 9

An alternative rendering of 'content-independence' is what I will refer to as the weak sense of content-independence. According to this rendering, the content-independence of, for instance, a law-given reason means that it does not derive its status as a reason from the content of a given legal provision, i.e. from the nature and merit of the action law requires. However, by this understanding of content-independence, the reason is not attributable to the mere fact that law requires the action. Rather, it depends on substantive factors (other than the content of the legal requirement), viz. attributes that a lawmaking institution may possess, such as the fact that legal requirements in the relevant jurisdiction ensue from a fair and just decision-making procedure; or that the relevant lawmakers are well placed (relative to private actors) to determine what ought to be done in certain situations or domains of activity; or that legal authorities, due to their salience and enforcement measures, are apt to facilitate beneficial coordination between people; or other possible attributes of a

plies that the reason for action is not the mere fact that law requires it. This construction arguably finds further support in Raz's qualified words "no direct connection" instead of simply "no connection". See also my caveat in note 9.

8 Green, supra note 1, p. 225.

9 Shapiro, supra note 1, p. 389. I do not make the claim that (some or all of the above authors necessarily endorse, or would subscribe to, the strong version of content-independence or to the idea that law is such a content-independent reason. I only cite the above statements as examples which suggest that this sense of content-independence figures in the literature and that content-independence can be understood in this way. 
lawmaking institution which, when present, militate in favor of compliance with its requirements (these will be frequently referred to as substantive considerations for law-compliance, law-following values, or the like). A clear expression of this sense of content-independence may be found, for instance, in the following remark of Raz: ${ }^{10}$

Take a rule saying that members [of a chess club] are entitled to bring no more than three guests to social functions of the club. The considerations which establish that it is binding do not turn on the desirability of members having a small number of guests, nor on the desirability of members having the option to bring guests, but on the desirability of the affairs of the club being organised by the committee which laid down the rule [which he attributes to "evaluative considerations" such as a recognition that "the harm that would be occasioned by a disorderly attempt to overturn" the rules of the committee "is too great"]. It is, in other words, an instance of what I call (following Hart) a content-independent justification. It is content-independent in that it does not bear primarily on the desirability of the acts for which the rule is a reason. ... [T] he considerations which show why the rule is binding, i.e. why it is a reason for not bringing more than three guests, do not show that it is good not to bring more than three guests. They show that it is good to have power given to a committee, and therefore good to abide by decisions of that committee. But that can justify a variety of rules. ... They are, in this sense, content-independent. ${ }^{11}$

10 Once more, I do not wish to make an exegetical claim that attributes to Raz a general endorsement of this sense of content-independence. I only quote this comment of his as an example of a statement that comports with that sense.

11 Raz, Joseph, "Reasoning with Rules", Current Legal Problems, vol. 54, 2001, pp. 1-18, at pp. 8-9. Other statements consistent with the weak sense are made, for example, by Duff, supra note 1, p. 247 (referring to content-independent reasons as "reasons which ... justify her [i.e. a ruler] in demanding obedience from the people at all-reasons which ... give her the right to issue commands or rules, and to back them by different threats") and by Thomas Christiano in "The Authority of Democracy", The Journal of Political Philosophy, vol. 12, 2004, pp. 266-90 (p. 267: "[I]f a process is genuinely democratic ... justice demands that individuals comply with the decision-making process. ... The demand is content independent: compliance is required regardless of the content of the democratic decision ..."; p. 287: "[O]nly by obeying the democratically made choices can citizens act justly. Demo- 
While this explanation, too, contains both a negative and a positive element, its positive element is different from that which appeared in the previously quoted statements. ${ }^{12}$ Here content-independent considerations are said to consist not simply and only in the fact that an authorized ruler has required an action, but rather in the desirability of allowing him to regulate the kind of affairs concerned. Now, I should note that, of the two alternative renderings I set out, only the latter is warranted by the label 'content-independent reasons' in itself. The only type of independence that the label refers to is content-independence, where 'content' is naturally understood as the content of a requirement; and this is exactly the type of independence I called weak. The strong type of independence, by contrast, envisages reasons that are independent of any substantive considerations or value judgment, whether content-based or other. The proper name for this idea would be not 'content-independence', but rather 'substance-' or 'value-independence'. Nevertheless, it would be wrong to rule out of consideration the strong rendering of content-independence, if only for the fact that it corresponds with the way content-independence has been understood and used by many legal theorists.

Another point that bears clarification at this stage is that neither the weak nor the strong sense of content-independence entail that when legal rules apply to us the only reasons we have are content-independent. Thus, it is not denied by any conception of content-independence that, insofar as the content of a law coincides with moral standards, some of the reasons for compliance with the law consist in the moral worth of what it requires. ${ }^{13}$ The claim we are considering, therefore, is that legal requirements provide content-independent reasons, not that content-inde-

cratic directives give content-independent reasons since one must accept a democratic decision as binding even when one disagrees with it").

12 Text accompanying notes 5-9.

13 Himma, supra note 1, p. 26. 
pendent reasons are exhaustive of the reasons applying to law's subjects.

So far we have seen that there exist two alternative senses of content-independence: a weak and a strong one. This means that our initial question -whether law provides content-independent reasons- actually envelops two different questions: (1) whether law provides content-independent reasons in the weak sense; (2) whether law provides content-independent reasons in the strong sense. I now turn to these questions.

\section{Does LaW Provide Weakly/Strongly Content- INDEPENDENT REASONS?}

The first of the two questions just listed appears to be the easier. For there is nothing problematic or perplexing in saying that the array of reasons that apply to law's subjects may include not only reasons grounded in the content of an applicable rule, but also considerations associated with some qualities of rules themselves, of the institutions that make them, or of the procedure from which they ensue. ${ }^{14}$ Thus, for instance, a recognition that the relevant lawmaking institution is better placed than a private actor to decide on certain matters, the conduciveness of legal rules to social order, stability and coordination, and their capacity to simplify and expedite daily decision-making, are all factors that when applicable count in favor of following legal rules. To use a concrete and familiar example: a rule requiring people to drive on the right presents them with a compelling coordination-related reason for doing so, which is independent of any value attached to driving on the right per se and would equally apply if the rule were to require

14 A question may arise, however, as to whether some of these reasons are excluded by the rule - I have discussed this question in Gur, Noam, "Legal Directives in the Realm of Practical Reason: A Challenge to the Pre-Emption Thesis", American Journal of Jurisprudence, vol. 52, 2007, pp. 159-228. 
driving on the left. ${ }^{15}$ This, of course, is just one, clear example of a coordinative rule, and there are many other types of legal rule that involve a coordinative dimension, contribute to determinacy and certainty in social life, and have other desirable aspects which are not specifically tied with the particular content adopted - values which compliance with the rule tends to protect and promote. It seems, therefore, that the answer to our first question, whether legal requirements give rise to content-independent reasons in the weak sense, is that they can and frequently do. ${ }^{16}$

Do legal requirements constitute content-independent reasons in the strong sense (i.e. reasons attributable, not to their content, but to the mere fact of their being legal)? It is tempting to respond with a simple "no". For one cannot help but wonder: how can the mere fact that an action is required by a lawmaker, his mere say-so, constitute a reason to act in and of itself? Human beings cannot create reasons out of thin air simply by requiring that others act in some way. An utterance of a lawmaker, the thought may continue, is no more than an artifact of the human will which cannot by itself turn a false moral proposition into a true one or determine by way of stipulation what is wrong and what is right. ${ }^{17}$ It can only have normative bearing when and insofar as it appears in conjunction with some non-artificial, evaluative factors which make it the case that, and explain why, it is good to follow the law -factors of the type mentioned in the preceding paragraph. ${ }^{18}$

15 True, this reason depends on the fact that the context of regulation is such that involves a coordination problem, but it remains independent of the particular content chosen by the legislature (within a certain range of possibilities). So, although this coordination reason depends on the regulated context, it is (in a limited, but important sense) content-independent.

16 That is, they do so when and insofar as the lawmaking procedure or institution has the attributes that make it desirable to follow legal directives.

17 A similar argument is mentioned by Hart, supra note 1, p. 265 (though he mentions it as part of a more moderate objection to his conception of authoritative reasons).

18 Idem. 
The problem with this argument is not so much what it says, but what it ignores. It overlooks a pertinent distinction between two ways of using the term reason: namely, a distinction between descriptive statements about reasons and evaluative statements about reasons. By "descriptive statements about reasons", I mean statements describing the reasons that figure in people's practical deliberation; or, more particularly, the kind of reasons that participants in a certain normative practice, such as law, characteristically deem themselves to be given by the requirements of that practice. Thus, in our context, a descriptive statement referring to reasons of type $\mathrm{X}$ conveys that within the boundaries of a particular normative practice actors regularly operate with an assumption that the practice's requirements provide them with reasons of type $X$. In contrast, evaluative statements about reasons, rather than describing the reasons that people take themselves to have, evaluate what reasons actually apply to them (with or without their knowledge of those reasons). Such statements ensue from a mode of inquiry that refuses to stop at the identification of the normative assumption prevalent among participants in the relevant practice, but rather looks beyond that assumption and seeks an ultimate and substantive explanation of what, if anything, makes it a correct assumption. ${ }^{19}$ In this sense, evaluative statements about reasons are committed, not to the viewpoint of the normative practice in question, but rather to the viewpoint of the normative universe at large. ${ }^{20}$

19 It might be argued that descriptive reason-statements are no more than parasitic on evaluative reason-statements, and that we should therefore concern ourselves solely with the latter. This argument is misguided not only because the question of how law figures in subjects' practical reasoning is an important question in its own right, but also because, as will become apparent in Section IV, the term 'parasitic' grossly oversimplifies what is in fact a complex relation between the descriptive and evaluative dimensions.

20 A few caveats should be made here: first, these evaluative statements concern only reasons that apply to participants in a given legal practice qua participants. They do not refer, for instance, to reasons applicable in the state of nature or to reasons that have nothing to do with law. Second, the evaluative perspective I 
Against this background it becomes apparent that there are two different ways in which strong content-independence can be spoken of: it can be used in a descriptive reason-statement, claiming that the legal practice is such that its participants typically treat its requirements as strongly content-independent reasons (and it bears noting here that the descriptive language is the one in which Hart's arguments about strong content-independence are usually couched ${ }^{21}$ ). Or it can be used in an evaluative reason-statement, claiming that legal requirements are strongly content-independent reasons from the viewpoint of the normative universe at large, not merely in the assumption of the legal practice. Now, the objection earlier posed against strong content-independence clearly presupposes and takes as its target the second, evaluative statement. And indeed the idea conveyed by this statement - that a word mouthed by a human agent can, by itself, create a reason to do what he says without there being any substantive factors that make it desirable to follow him - is clearly untenable. And even when it comes to legal rules whose formation is associated with social facts other than the utterance or will of a human legislator, such as social customs, it would be an unwarranted leap (from a non-evaluative premise to an evaluative conclusion) to say that the mere fact of their existence constitutes reasons to act in the absence of substantive factors that show why it is good or morally right to comply with them. Evaluative statements about reasons necessarily depend for their correctness on the underpinning force of such substantive factors. Thus, the only type of content-independence that can correctly figure in an

refer to can be entertained by participants themselves, even if this is not likely to occur in the usual course of their practical operation, but in more reflective modes of deliberation or conversation. Third, despite its readiness to transcend the normative assumptions of the legal practice, this evaluative perspective is entirely different from the type of external viewpoint that Hart famously criticized, namely that which overlooks the normative dimension of law and focuses solely on regularities of behavior.

21 Hart, supra note 1, pp. 18, 243-68. 
evaluative statement is one that allows for such factors -i.e. the type of content-independence I entitled weak.

Before turning to consider the descriptive statement about strong content-independence, I should make a couple of caveats in this regard: first, my arguments will not purport to describe how all or even virtually all participants in the legal practice treat its requirements, but rather will only claim to identify salient attitudes that seem to characterize at least a significant proportion of participants in typical legal systems. Second, I will not adduce experimental or survey-based empirical evidence with regard to these descriptive claims, but rather will confine myself to phenomenological observations and anecdotal evidence from ordinary human experience. This, I admit, limits the probative force of these descriptive claims, which will therefore be offered here as merely provisional observations rather than conclusive findings. With these caveats in mind, let us consider the notion of strong content-independence at the descriptive level: do participants in the legal practice regularly treat its requirements as providing them with content-independent reasons in the strong sense, i.e. as providing them with reasons by virtue of being legal? At first glance, the answer appears to be a simple "yes". Consider, for example, the way people intend and understand a sign that says "Buckle up! It's the law" or "It is against the law to smoke in these premises". The formulator of this sign intended to present its readers with a reason to act in the specified manner and this is what readers of the sing commonly understand. To be thus understood all that the formulator said, and needed to say, is this: "It's the law" or "It is against the law". This way of perceiving law is, of course, not limited to communication through signs. Thus, for instance, if an official in charge of enforcing a smoking ban in certain public spaces were to be asked "why?" when fining a violator and demanding him to stop, his response may well be: "because you are breaking the law"; and if an ordinary citizen were to be asked, upon 
stopping her car at a red traffic light, why she had stopped, her (surprised) response would probably be simply to point at the red light or to say that this is what the law requires.

Indeed, that participants in the legal practice, who share its internal point of view, regularly treat laws in the way just exemplified is a point famously made by Hart in The Concept of Law.22 And although, for Hart, a society may have a legal system even if its private citizens, as opposed to public officials, do not share the internal point of view, he nonetheless referred to a society in which they largely do not as an extreme case, and maintained that in normal societies citizens will often assume it. ${ }^{23}$ For such citizens, as Hart noted, "the red light is ... a reason for stopping in conformity to rules which make stopping when the light is red a standard of behaviour and an obligation",24 and when a legal official punishes law violation, according to Hart, he "takes the rule as his guide and the breach of the rule as his reason and justification for punishing".25 Of course, these statements of Hart were not primarily concerned with the idea of content-independence, but rather more generally sought to highlight the normative dimension of law and counter the type of reductionism that analyzes the legal practice in terms of behavioral regularities alone. Nevertheless, by recognizing that legal rules are regarded as reasons while omitting reference to the merits of the required action or to substantive law-following values, Hart lends implicit support to what he elsewhere explicitly calls content-independence, at least as far as it figures in descriptive reason-statements. ${ }^{26}$

22 Hart, H. L. A., The Concept of Law, 2nd. ed., Oxford, Oxford University Press, 1994, pp. 11, 55-6, 89-90.

23 Ibidem, p. 116-7.

24 Ibidem, p. 90.

25 Ibidem, p. 11 (emphases omitted). See also related comments at ibidem, p. 55.

26 Hart, supra note 1, pp. 243-68. Hart acknowledges that normative acceptance of law may (though need not) be based on one's recognition of the moral value of the system (ibidem, pp. 256, 265-6; Hart, supra note 22, pp. 203, 257). The distinction I will draw between actions and attitudes (in text accompanying notes 
But even this descriptive statement about (strong) content-independence may be challenged. It may be challenged on grounds that were usefully highlighted by one of Neil MacCormick's arguments regarding Hart's account. ${ }^{27}$ MacCormick acknowledges that participants in the legal practice who share the internal point of view typically take its rules to provide them with reasons for action. Conversely to Hart, however, he stresses that acceptance of legal rules from the internal perspective is not unreasoned, but rather must be, or at least normally is, underpinned by a judgment on the part of participants about the value and justice of the system: e.g. their recognition that the system beneficially contributes to certainty and predictability, that the power exercised by lawmakers derives legitimacy from the fact of their being democratically elected, and that laws are enacted through a procedure which is by and large fair and just. ${ }^{28}$ If, as MacCormick observes, such substantive factors undergird the acceptance of rules by their subjects, this may be thought to show that rules are not treated as content-independent reasons in the strong sense, i.e. in the sense that signifies independence of those substantive factors. Now, I will accept the kernel of MacCormick's claim, but will suggest that its effect is merely to qualify, rather than utterly to refute the notion of strong content-independence as a description of how law operates in people's

30-37) can reconcile such morally based acceptance of law with Hart's endorsement of strong content-independence: Hart can be taken to mean that even when people's law-abiding attitude is underpinned by a moral judgment, it tends to influence their actions independently of a case-by-case assessment of law-following values, which means that law operates in their practical reasoning as a strongly content-independent reason for action.

27 MacCormick, Neil, Legal Reasoning and Legal Theory, Oxford, Clarendon Press, 1978, pp. 63-4, 139-40. See generally Smith, J. C., Legal Obligation, London, Athlone, 1976, pp. 22-33; Dworkin, Ronald M., Taking Rights Seriously, London, Duckworth, 1978, pp. 51-8; Finnis, John M., Natural Law and Natural Rights, Oxford, Clarendon Press, 1980, pp. 13-4; Finnis, John M., "On Hart's Ways: Law as Reason and as Fact", American Journal of Jurisprudence, vol. 52, 2007, pp. 25-53; Perry, Stephen R., "Hart's Methodological Positivism", in Coleman, Jules L. (ed.), Hart's Postscript, Oxford, Oxford University Press, 2001, pp. 330-47.

28 MacCormick, ibidem, pp. 63-64, 139-40. 
practical reasoning. What ought to be accepted as plausible is that people's normative adherence to legal rules is partly underpinned by a recognition that the system helps secure at least basic goods in social life and conforms to principles of justice at least to a minimal degree that makes it acceptable. ${ }^{29}$ Consistently with MacCormick, it seems to me highly unlikely that people could honestly come to believe that legal rules give them normative reasons without this belief being influenced or validated by any notion that there are some actual reasons to follow the law. ${ }^{30}$ For people, even those in possession of only the most basic level of human rationality and understanding, can hardly fail to comprehend what was earlier observed here as a straightforward verity: namely, that reasons to act cannot be magically brought into existence by the mere word of an agent without there being some substantive factors that make it desirable to follow his word. ${ }^{31}$

Nonetheless, it seems to me that the role played by law-following values in subjects' practical reasoning is not entirely inconsistent with the idea of strong content-independence. Rather, it only shows that this idea ought to be qualified. The reason for this is that, although law-following values seem to play a part in leading subjects to adopt the general attitude they normally have towards law -i.e. their law-abiding disposition, the attitude of treating law as a

29 Which is compatible with people's being dissatisfied with certain aspects of the system, its officials, or the political party in power.

30 Hart mentions MacCormick's objection without discussing it (Hart, supra note 22 , p. 243). He seems to retain his position that allegiance to the system need not stem from a moral judgment, but "may be based on many different considerations: calculations of long-term interest; disinterested interest in others; an unreflecting inherited or traditional attitude; or the mere wish to do as others do" (ibidem, pp. 203, 257; Hart, supra note 1, pp. 256-7). For reasons explained in the main text above, I think these remarks of Hart fail to meet MacCormick's challenge. A better response to MacCormick can be given by recourse to the actions / attitudes distinction - see text accompanying notes 30-37.

31 This would, inter alia, involve attributing to people the assumption that "there were two independent 'worlds' or sets of objective reasons, one legal and one moral" - which even Hart refers to as an "extravagant hypothesis" (Hart, supra note 1, p. 267). 
reason for action - the influence of that attitude on their actions does not depend on whether law-following values apply to the particular situation they face. This requires an explanation: We sometimes use the phrase a law-abiding citizen. When employing this phrase, obviously we are not referring to an action, not even to a series of actions, but rather we are characterizing an agent. We are pointing out, more specifically, a certain attitude of the person in question: a law-abiding disposition, an attitude whose possessors generally treat law's requirements as reasons for them to act accordingly. What does the attitudinal dimension implied here add and how precisely does it differ from simply speaking of actions? The attitudinal dimension suggests (or at least allows for the possibility) that the law-abiding disposition referred to is a well-entrenched and deep-seated feature of its possessors which tends to endure through time, rather than being just a momentary response to a particular situation. ${ }^{32}$ It suggests that, once adopted, the disposition exerts its influence on its possessor's actions independently of a case-by-case assessment of the reasons that led to its adoption, and that it may thus make its force felt even when those reasons are absent. Once adopted, in other words, it exerts its force independently of whether substantive considerations in favor of following the law apply to the particular case at hand (and this, it bears clarification, is consistent with saying that the force of the disposition remains overridable by substantive contrary reasons, rather than absolutely and exclusively determinative of one's actions $\left.{ }^{33}\right)$.

32 I say "tends" because dispositions need not be permanent; people sometimes abandon or change some of their dispositions. Doing so, however, may be difficult and normally takes time. It is not done on a case-by-case basis.

33 To see this, it may be helpful to think of this law-abiding attitude in terms of an inclination: on the one hand, it is not a simple, constantly malleable reflection of substantive reasons for and against compliance as applicable in specific cases -if it were only that, there would be no point or distinct significance to calling it an inclination. On the other hand, being no more than an inclination, it stops short of excluding relevant case-specific reasons and remains overridable by such reasons. 
Before I turn to explicate how precisely the attitude/action distinction bears on our question, it may be useful to shed more light on the distinction itself by reference to an example. I said that the envisaged law-abiding disposition makes its influence felt independently of whether the reasons for having it, i.e. law-following values, apply to a particular action in a particular situation. One implication of this is that those who are thus disposed to comply with law may be led to perform actions which they would not perform if they were guided solely by the balance of reasons for action. Consider, as a case in point, the frequently invoked hypothetical of a traffic light in the desert. ${ }^{34}$ It runs (with certain variations) along the following lines: you are driving on a lonely road in the desert. You come to an intersection where there is a red traffic light. The law prohibits driving through a red light, but with a perfectly flat and desolate landscape around you, you can tell that there are no other vehicles or pedestrians within miles in any direction. It is evident that an act of non-compliance on your part will not be seen or discovered by anyone else. So it will not result in your being punished and will not stimulate other actors into disobedient behavior. Also suppose that - given how astute and strong-willed you are, or given other features of your personality or condition - running a red light in this special situation will not weaken your resolve to comply with the law in other circumstances. As many philosophers acknowledge, in this type of situation there is no real reason (whether safety, coordination, or other) for you to stop and wait for the light to turn green. ${ }^{35}$ And even if some

34 See Raz, Joseph, The Authority of Law, Oxford, Clarendon Press, 1979, p. 16; Smith, M. B. E., "Is There a Prima Facie Obligation to Obey the Law", Yale Law Journal, vol. 82, pp. 950-76, at p. 971; Regan, Donald H., "Law's Halo", Social Philosophy and Policy, vol. 4, 1986, pp. 15-30, at pp. 18-9; Hurd, Heidi M., "Challenging Authority", Yale Law Journal, vol. 100, 1991, pp. 1611-77, at p. 1614; Edmundson, supra note 3, pp. 12-34.

35 See, e.g., Smith, ibidem, p. 971 and Regan, ibidem, pp. 18-9. See also Alexander, Larry, "Law and Exclusionary Reasons", Philosophical Topics, vol. 18, 1990, pp. $5-22$, at p. 8 (noting that "in situations where I predict no effect on others' behavior, no detection of my disobedience, and no sanctions, my reasons against $A$ 
such reason for action could be said to apply to the case it would be too remote and weak to rationalize an act that is, in all other respects, sharply inconsistent with common sense: stopping and waiting when there is absolutely no traffic and not a single soul for miles around. If so, assuming that your action is guided purely by a correct assessment of the balance of reasons for action, you will violate the law in these circumstances. The case may well be different, however, if you act with a general disposition to comply with law. If such a disposition characterizes your attitude towards law, and if it is sufficiently forceful and deepseated, it is likely to lead you to stop and wait for the light to change after all. ${ }^{36}$

At this point an objection might be raised against the premise that the supposed driver in the desert-traffic-light

[where $A$ is a legally prohibited action] remain exactly as they were before the law was enacted"). Raz notes with regard to a similar example that "[m]any will say that there is not even the slightest reason to stop at the red light in such circumstances" (ibidem, p. 16). Without explicitly committing himself to the above view, he says that "[t]his example seems sufficient to convince one that in this case or a similar case the utterance of authority can be held to be legitimate without holding them to constitute reasons for action" (idem).

36 These remarks are consistent with saying (as I will in Section IV) that people have good reason to adopt the envisaged law-abiding disposition (even if it would occasionally lead them to perform actions they have no reason to perform). Moreover, I do not wish to deny that there is a certain sense in which an act of compliance in the desert-traffic-light situation could be described as a rational act (though that sense is not the one contemporary philosophers commonly use when describing an act as rational): if an agent has acquired a disposition, such that it is rational to acquire, and this disposition leads her to comply with law, inter alia, in the desert-traffic-light situation, one might suggest that her act of compliance is rational in the sense that it ensues from a disposition whose acquisition was rational (see analogous arguments in Gauthier, David, "Afterthoughts", in MacLean, Douglas (ed.), The Security Gamble, Totowa, NJ, Rowman \& Allanheld, 1984, p. 159; Gauthier, David, "Rethinking the Toxin Puzzle", in Coleman, Jules L. and Morris, Christopher W. (eds.), Rational Commitmentand Social Justice, Cambridge, Cambridge University Press, 1998, p. 47; Pink, Thomas, The Psychology of Freedom, Cambridge, Cambridge University Press, 1996, p. 93). But this sense of 'rational act' does not mean that the act is supported by the balance of reasons for action. Normative reasons for action, as I understand them, are facts linked with qualities of the action itself or its consequences (including consequences it has qua an act of compliance or non-compliance). To establish that one has a reason to perform a certain action, it must be shown how performance of that specific action, given the specific circumstances in question, would serve a specific value. The mere fact that an action ensues from a rationally adopted disposition is not a reason for action. 
situation has little or no reason to stop. The objection I have in mind contends that the driver would be right to reason as follows: A. It is good (for reasons such as the desiderata of social order, coordination, etc.) generally to obey the law in a society like ours. B. The law requires people not to drive through a red light. C. The conjunction of A and B entails that I have a good reason to stop at the red light in front of me. The problem with this three-step reasoning is that it tars with too broad a brush: to establish that there are real reasons for action (i.e. the action of stopping) in the desert-traffic-light situation, it must be shown that the considerations which are said to make it good "generally" to obey the law apply in that situation, i.e. that an act of obedience in that specific situation would genuinely serve those substantive values. This, however, sends us back to the previous paragraph, where I pointed out the lack of rational basis for an act of obedience in that situation. In fact, the objector's readiness to settle for "it is good generally to obey the law" and to gloss over the absence of substantive reasons for compliance in the example at hand may be attributable to his having precisely the same tendency which I call a law-abiding disposition. ${ }^{37}$

We are now in a position to provide a sufficiently qualified response to the question of whether law's subjects treat its requirements as strongly content-independent reasons. If I am right to argue that law-following values help leading subjects to adopt a certain attitude towards law - such that they regard the fact that law requires $X$ as a reason for them to perform $\mathrm{X}$ - and that the influence of that attitude on their actions does not depend on whether law-following values apply to the particular situation they face, then the answer is this: law typically operates in the practical reasoning of its subjects as a strongly content-independent

37 See Edmundson, supra note 3, p. 27. One can think of a more sophisticated version of the above objection which appeals to considerations of 'fair play' (standing alone or combined with consequentialist considerations). For an explanation of why such an argument would fail in the circumstances discussed, see ibidem, pp. 28-31. 
reason for action, though subjects adopt this attitude towards law (i.e. the attitude which implies that they treat it as a strongly content-independent reason) due to reasons which are not content-independent in the strong sense. ${ }^{38}$ Thus, the notion of strong content-independence may be adequately used to describe the way things look from the internal point of view insofar as reasons for action are concerned, but its explanatory force does not extend to reasons for attitudes.

The following observations emerge from the analysis thus far: (1) content-independent reasons can be understood in either a strong sense (ascribing the reason to the mere fact that law requires an action) or a weak sense (ascribing the reason to substantive factors other than the nature and merits of the action law requires). (2) While weakly content-independent reasons are an unproblematic notion, strong content-independence is a more questionable concept whose plausibility turns, in part, on a further distinction: a distinction between evaluative statements about reasons (evaluating what reasons people have from a normative perspective not limited to the internal assumptions of their practice) and descriptive statements about reasons (describing the reasons participants in a certain

38 I do not wish to take sides here in the philosophical debate regarding state-given and object-given reasons (to use Derek Parfit's terminology): namely, I will take no stance on whether the reasons I referred to in the main text above should be classified as (state-given) reasons to have the relevant attitude or (object-given) reasons to try to bring it about that we have it or to cause ourselves to have it. The wording I will be using mostly - 'reason to adopt a disposition/attitude'- is, I think, reconcilable with either of these alternatives, and even when I will use a less neutral formulation (such as reasons for attitudes), I will do so merely for ease of reference. As for the above debate, see e.g. Parfit, Derek, "Reasons and Rationality", in Egonsson, Dan et al. (eds.), Exploring Practical Philosophy, Burlington, VT, Ashgate, 2001, pp. 17-39; Dunn, Robert, "Akratic Attitudes and Rationality", Australasian Journal of Philosophy, vol. 70, 1992, pp. 24-39; Olson, Jonas, "Buck-Passing and the Wrong Kind of Reasons", Philosophical Quarterly, vol. 54, 2004, pp. 295-300; Hieronymi, Pamela, "The Wrong Kind of Reason", Journal of Philosophy, vol. 102, 2005, pp. 437-57; Piller, Christian, "Content-Related and Attitude-Related Reasons for Preferences", Philosophy, vol. 81, 2006, pp. 155-81; Morauta, James, "In Defence of State-Based Reasons to Intend", Pacific Philosophical Quarterly, vol. 91, 2010, pp. 208-28. 
normative practice characteristically take themselves to have). (3) Strong content-independence is clearly untenable when it appears in evaluative reason-statements. When figuring in descriptive reason-statements, however, it ought to be assessed in light of a further distinction: a distinction between reasons for action and reasons for attitudes. (4) While it appears descriptively correct to say that law typically operates as a strongly content-independent reason for action in the practical reasoning of its subjects, it ought to be acknowledged that the attitude of treating law that way is acquired by subjects on account of reasons which are not strongly content-independent reasons.

\section{A DiscRepancy With Good REASON}

One particularly noticeable aspect of the foregoing analysis is the finding of a discrepancy between the type of content-independence evaluatively warranted and the type of content-independence that corresponds with the way subjects actually reason about their actions. On the one hand, when we evaluate what reasons subjects have in normative terms unbounded by the internal assumptions of the legal practice, the idea of strong content-independence appears to lack even minimal plausibility; from this viewpoint, the only acceptable type of content-independence is the weak one. On the other hand, when we focus attention on the practical assumptions of participants in the legal practice, it appears that they typically treat law's requirements as strongly content-independent reasons for action; they regard the fact that law requires an action as a reason for its performance independently of whether substantive law-following values apply to their situation.

How are we to explain this discrepancy? Should we conclude that the characteristic approach of law's subjects is the product of a sheer error on their part? Or is there a less radical explanation of the relation between the reasons that truly apply to subjects and the way they actually reason, 
i.e. one that makes sense of the latter in terms of the former? It appears to me, prima facie, that such an explanation is likely to exist. For it is highly improbable that the socially prevalent perception of law's normative force, as developed over millennia and across many cultures, is the result of an accidental human error. Even if that perception is in some sense mistaken, there are likely to be good reasons why it developed the way it did. It is plausible that the shape and content it came to have are such that fulfill some valuable functions in social life. That said, it should be clarified that these intuitive assumptions are not stated here as a constitutive element of my argument or a premise on which I seek to rely. Their only role is to serve as a background to what will be a self-contained argument about the "good reasons" or "valuable functions" that may justify treating legal requirements as strongly content-independent reasons. I now turn to this argument.

I will initially put forth a basic hypothesis about the justification for treating law as a provider of strongly content-independent reasons. This hypothesis will be cast in a rather general and abstract form, but will then be substantiated and filled out with more concrete content. The hypothesis is this: the subjects of a reasonably just legal system should treat its requirements as providing them with strongly content-independent reasons for action (rather than reasons that depend on content or on whether law-following values apply to their situation) because by so doing they would be more likely to conform to substantive reasons that apply to them in the areas that law regulates. Now, this justificatory hypothesis may strike a familiar chord with readers of contemporary jurisprudence; it resonates, of course, with Raz's normal justification thesis, according to which "the normal way to establish that a person has authority over another person involves showing that the alleged subject is likely better to comply with reasons which apply to him ... if he accepts the directives of the alleged authority as authoritatively binding and tries to follow 
them, rather than by trying to follow the reasons which apply to him directly". ${ }^{39}$ Notwithstanding their close affinity, however, there are a number of pertinent respects in which my justificatory hypothesis differs from Raz's normal justification thesis: (1) the two do not seek to justify the same thing. According to Raz, insofar as an alleged authority satisfies the condition stated in the normal justification thesis, it gains the status of a legitimate authority, which means that (to this extent) its directives become pre-emptive reasons, reasons for action that exclude some otherwise applicable reasons. This is significantly more than what my hypothesis seeks to establish: firstly, I do not suggest that certain directives (or the fact that they were issued) are reasons, but only that it is desirable that, in our daily operation as subjects of the law, we treat them as reasons; 40 secondly, my argument does not refer to pre-emptive reasons, but rather to content-independent reasons. These are two distinct concepts, for a reason can be independent of content without excluding any other reasons. ${ }^{41}$

(2) While the normal justification thesis states what Raz conceives of as the (main) condition under which a government would acquire legitimate authority, it does not contend that governments, or even reasonably just governments, generally do satisfy that condition. In fact, in several places Raz denies that they generally do - as, for example, when he says that "political authorities are likely to have more limited authority [in the legitimate sense] than the authority many, perhaps all of them, claim to have, and that people generally believe they have". ${ }^{42}$ In contrast, my hy-

39 Raz, supra note 1, p. 53 (emphasis omitted). See also Green, supra note 1, p. 56.

40 See Alexander, supra note 35.

41 As noted, I have discussed Raz's pre-emption thesis and exclusionary reasons conception elsewhere (Gur, supra note 14).

42 Raz, Joseph, "The Problem of Authority", Minnesota Law Review, vol. 90, 2006, pp. 1003-44, at p. 1008. See also Raz, supra note 1, pp. 70-80, 99-104; Raz, Joseph, Ethics in the Public Domain, rev'd paperback ed., Oxford, Clarendon Press, 1995, pp. 341, 347-50. Following his above-quoted comment Raz says: "This still requires explaining why people are so mistaken ...", and he adds in a footnote that this is a point orally made to him by H. L. A. Hart (Raz, The Problem of Authority, 
pothesis does not merely state the condition under which it would be justified to regard law as providing strongly content-independent reasons, but rather also contends that, given a reasonably just legal system, the condition is generally fulfilled.

(3) Closely related to the preceding point, while Raz provides a general and abstract statement of the condition for acquiring legitimate authority, i.e. his normal justification thesis, he does not extensively discuss the concrete factors that enable authorities to meet that condition (insofar as they do). When he pronounces on the matter, however, he stresses two main factors:43 first, comparatively superior knowledge and expertise that an authority may have regarding the substance it regulates; ${ }^{44}$ second, the authority's capacity to secure and facilitate social coordination between its subjects. ${ }^{45}$ Now, bearing out my own hypothesis will require a close look at the underlying substantive factors that may justify treating legal requirements as strongly content-independent reasons. This will yield a picture rather different from the one Raz appears to envisage: it will be observed that while differential expertise and coordinative ca-

ibidem, pp. 1008-9 and fn. 11). I agree with this last remark. As earlier indicated, it seems to me that although the socially prevalent attitude towards law's normativity may be in some sense mistaken, it is not likely to have evolved through arbitrary processes leading to senseless implications for our life in society. My analysis in this Section is an attempt to explain the sense and value of the prevalent normative attitude.

43 He notes: "The two basic arguments for authority depend on its ability, through concentrating expertise on various issues, to overcome common ignorance and on its ability to help solve common difficulties in securing coordination" (Raz, Joseph, Practical Reason and Norms, 2nd. ed., Princeton, Princeton University Press, 1990, p. 195). Another factor that seems to play a significant role in Raz's conception of legitimate authorities is their ability to provide a framework within which social life can proceed in the face of fundamental disagreements and differences between members of society (Raz, supra note 1, p. 58). The arguments I will make as to comparative expertise and coordinative capacities of authorities also apply, mutatis mutandis, to their ability to bridge such ideological gaps.

44 Raz, supra note 43, pp. 63-4, 195; Raz, supra note 11, pp. 14-5.

45 Raz, supra note 43, pp. 64, 195; Raz, Joseph, "Facing Up: A Reply", Southern California Law Review, vol. 62, 1989, pp. 1153-253, at pp. 1191-3; Raz, supra note 11 , pp. 14-5. See further on the coordinative role of authorities in Raz, supra note 1, p. 49. 
pacities are relevant factors, the root of the justification lies elsewhere, in factors that Raz touches upon, but whose implications he never acknowledges ${ }^{46}$ —indeed, when closely examined, these factors seem to suggest that the ordinary scope of legitimate governmental authority is significantly more general and less piecemeal than Raz believes it to be.

I now turn to verify my hypothesis. Consider, first, the justificatory force of factors of the type mentioned in the preceding paragraph: i.e. epistemic considerations for compliance with law such as the recognition that one's knowledge and expertise as to a legally regulated matter are inferior in comparison to the lawmaker's, or non-epistemic considerations such as the recognition that an act of compliance would contribute to social coordination. Do these law-following values, in themselves, explain why treating legal requirements as strongly content-independent reasons (i.e. reasons independent of law-following values) is requisite for making optimal use of law as a guide to right action? The answer seems to me to be negative. Nothing in the mere facts that a legal authority enjoys relative expertise and possesses coordinative abilities prevents these facts from being adequately considered and given due weight in the practical reasoning of law's subjects. Thus, for example, if a regulator has greater expertise than mine on a certain matter, I can factor his comparative expertise into my respective decisions by treating the case for doing what he prescribes as weightier than it would have seemed to me otherwise; and the degree of extra weight I thus accord to the prescribed conduct can, and seemingly should, be sensitive to the degree of expertise the regulator has on the relevant matter, in much the same way that the weight I accord to an investment advice would be sensitive to whether it was given to me by the consultant at my local bank branch or by, say, Warren Buffett. This holds true also in respect of non-epistemic factors such as consider-

46 See his reference to biases in Raz, supra note 1, p. 75. The deficiencies of his position will be explained in note 48 . 
ations of social coordination: for, firstly, the relative importance of coordination may vary with the context and type of activity concerned; secondly, not all laws are equally conducive to goals of coordination; and, thirdly, even laws that are in general conducive to coordination goals may, on occasion, fail to serve and even contravene these very goals. Surely, the correctness of practical decisions partly depends on these variables. When we focus attention on differential expertise or social coordination, therefore, it is hard to see why law's subjects should not treat its normative force as conditional upon these factors, i.e. as content-independent in the weak sense.

There are, however, other factors that emphatically militate against the mode of practical reasoning associated with weak content-independence and recommend treating law as a provider of strongly content-independent reasons. The most significant of these factors, I will argue, is certain human biases and fallibilities to which we are commonly susceptible in our typical decision-making environment as law's subjects. ${ }^{47}$ More particularly, I will advance the following twofold argument: (1) due to certain stimuli present in the decision-making environment in which law's subjects typically operate, an assessment of law-following values which they carry out in this environment is likely to be influenced by certain biases pulling towards non-compliance; ${ }^{48}$ (2) the influence of those biases can be effectively

47 Another practical difficulty with the mode of reasoning associated with weak content-independence is that carrying out a complete assessment of reasons for compliance in each and every situation would require an exceedingly large amount of time and effort on the assessor's part, making this method of reasoning an extremely inefficient one.

48 Raz notes that one of the factors capable of establishing the legitimacy of authority is its having "a steadier will less likely to be tainted by bias, weakness or impetuosity, less likely to be diverted from right reason by temptations and pressures" (Raz, supra note 1, p. 75). Yet his account fails to accommodate the implications of biases. As will become clear in the following paragraphs, the relevance of biases is pervasive: first, the biases pertinent to our question are common human biases to which most of us, not only the unwise or reckless, are susceptible when operating in our typical decision-making environment as law's subjects; second, law's aptness as measure against those biases is primarily a function of basic 
counteracted by adopting an attitude which involves treating law itself as a reason for action independently of one's assessment of law-following values as applicable to the situation at hand: 49 precisely because this perceived reason operates independently of one's assessment of law-following values -i.e. operates as a strongly content-independent reason- it remains free from the biases which affect that assessment and can effectively counterbalance those biases. 50

What biases, then, are prone to influence an assessment of law-following values made by subjects in their typical decision-making environment? Since I have comprehensively discussed these biases elsewhere, herein I will confine myself to a relatively brief account focusing on three of them. 51 Consider, first, the tendency known to psychologists as self-enhancement bias or the better-than-average effect: 52

structural features commonly present in legal systems, e.g. the generality and prospective character of legal enactments. All this suggests that, under reasonably just and competent lawmaking institutions, as those found in familiar legal systems, the condition stated in the normal justification thesis is fulfilled widely and generally, rather than in the narrow and piecemeal manner Raz envisages.

49 I do not suggest that law is a suitable measure against the relevant biases because lawmaking officials possess personal qualities that make them bias-immune individuals (which is, of course, not the case). Rather, law can fulfill this role primarily because the settings and mode of decision-making in which lawmakers typically operate are significantly less susceptible to those biases than the settings and mode of decision-making in which subjects typically operate.

50 Cannot the relevant biases be effectively counteracted by the legal system's generating prudential reasons for compliance in the form of punishment? While generating prudential reasons for compliance is an essential part of the solution, the impracticality and unattractiveness of a system of governance that would depend for its efficacy solely or mainly on the use of coercive force and on the fear of punishment explain the need for another measure against common biases.

51 Manuscript on file with author (forthcoming, Oxford University Press, 2013).

52 See, e.g., Baumhart, Raymond, An Honest Profit: What Businessmen Say About Ethics in Business, New York, Holt, Rinehart and Winston, 1968, pp. 20-5; Larwood, Laurie and Whittaker, William, "Managerial Myopia: Self-Serving Biases in Organizational Planning", Journal of Applied Psychology, vol. 62, 1977, pp. 194-8; Svenson, Ola, "Are We All Less Risky and More Skillful Than Our Fellow Drivers", Acta Psychologica, vol. 47, 1981, pp. 143-8; Brown, Jonathon D., "Evaluations of Self and Others: Self-Enhancement Biases in Social Judgments", Social Cognition, vol. 4, 1986; Kruger, Justin and Dunning, David, "Unskilled and Unaware of it: How Difficulties in Recognizing One's Own Incompetence Lead to In- 
when people evaluate their own performance and skills in comparison with others', most of them rate themselves as better than the average person, with a disproportionately large percentage placing themselves towards the top end of the comparative scale.53 Thus, for example, experimental evidence suggests that the majority of drivers take themselves to be more skilful and less risky than the average driver (which obviously signifies an inflation in self-appraisal). ${ }^{54}$ The relevance of this bias becomes clear once it is brought to mind that, for an actor to correctly assess the weight of reasons to follow the guidance of an authority, rather than his own view on the merits, he must estimate the relative reliability or unreliability of his own judgment, knowledge, and skill as to the subject of regulation. To use again driving as an example, a driver who acts on his own assessment of the reasons for and against following the legal speed limit, overtaking restrictions, or other traffic rules, should take into account the degree to which his knowledge about traffic matters may be inferior relative to the road authority's, as well as the full extent of his shortcomings and actual limits of his ability as a driver. Self-enhancement bias, however, means that he is liable to underestimate these factors.

Consider, next, the tendency frequently referred to in psychological parlance as self-serving bias: when people make judgments about practical matters that bear on their self-interest, more often than not, they evaluate data and perceive moral principles in a manner beneficial to them-

flated Self-Assessment", Journal of Personality and Social Psychology, vol. 77, 1999, pp. 1121-34. See also: Cross, K. Patricia, "Not Can, But Will College Teaching Be Improved?", New Directions for Higher Education, vol. 1977, pp. 1-15.

53 See references in note 52 . Note that the observation is not that people always suffer from this bias. Rather, what has been observed is a general tendency; a pattern that characterizes most people's perception of their performance and skill. A similar caveat applies to the other biases discussed here.

54 Svenson, idem. See also Preston, Caroline E. and Harris, Stanley, "Psychology of Drivers in Traffic Accidents", Journal of Applied Psychology, vol. 49, 1965, pp. 284-8. 
selves. ${ }^{55}$ Thus, even if the decision ensues from a process of reasoning that is not wittingly egoistic, excessive weight is nonetheless likely to be ascribed to those considerations that coincide with the decision-maker's needs and wants at the expense of other relevant considerations. That such tendency exists in people was long ago noticed by thinkers such as John Locke, 56 David Hume, 57 and Albert Venn Dicey, ${ }^{58}$ and has been borne out by a large body of empirical studies in more recent times. ${ }^{59}$ Now, the pertinence of this bias in the context of our inquiry transpires once it is recalled that law makes social life and human cooperation possible by imposing on individuals restrictions and burdens which are often at variance with their nearest self-in-

55 Messick, David M. and Sentis, Keith P., "Fairness and Preference", Journal of Experimental Social Psychology, vol. 15, 1979, pp. 418-34; Messick, David M., "Social Interdependence and Decision Making", in Wright, George (ed.), Behavioral Decision Making, New York, Plenum, 1985, pp. 94-100; Thompson, Leigh and Loewenstein, George, "Egocentric Interpretations of Fairness and Interpersonal Conflict", Organizational Behavior and Human Decision Processes, vol. 51, 1992, pp. 176-97; Babcock, Linda and Loewenstein, George, "Explaining Bargaining Impasse: The Role of Self-Serving Biases", The Journal of Economic Perspectives, vol. 11, 1997, pp. 109-26; Dawson, Erica, Gilovich, Thomas and Regan, Dennis T., "Motivated Reasoning and Performance on the Wason Selection Task", Personality and Psychology Bulletin, vol. 28, 2002, pp. 1379-87. See further: Pogarsky, Greg and Babcock, Linda, "Damage Caps, Motivated Anchoring, and Bargaining Impasse", Journal of Legal Studies, vol. 30, 2001, pp. 143-59.

56 Locke, John, Two Treatises of Government, 2nd. ed., Cambridge, Cambridge University Press, 1967, bk. II, ch. IX, § 324, noting that, in the state of nature, "though the law of Nature be plain and intelligible to all rational Creatures; yet Men being biassed by their Interest ... are not apt to allow of it as a Law binding to them in the application of it to their particular Cases".

57 Hume, David, A Treatise of Human Nature, Oxford, Clarendon Press, 1888, bk. III, pt. II, § VII: "As violent passion hinders men from seeing distinctly the interest they have in an equitable behaviour towards others; so it hinders them from seeing that equity itself, and gives them a remarkable partiality in their own favour".

58 Dicey, Albert V., Lectures on the Relation Between Law and Public Opinion in England During the Nineteenth Century, 2nd. ed., London, Macmillan, 1914, p. 15: " $[\mathrm{M}]$ en come easily to believe that arrangements agreeable to themselves are beneficial to others. A man's interest gives a bias to his judgment far oftener than it corrupts his heart. ... He overestimates and keeps constantly before his mind the strength of the arguments in favour of, and underestimates, or never considers at all, the force of the arguments against ...".

59 See references in note 55 . 
terest and immediate preference - as, for instance, when the law prohibits manufacturers from emitting harmful substances or levies a tax on people's income. When subjects are faced with such restrictions or burdens, therefore, their assessment of the reasons for and against compliance is likely to be tainted by a self-serving bias, leading them to perceive the facts and balance reasons in a manner that is somewhat overly sensitive to their individual circumstances and needs. If they were to act solely on such an assessment, they would thus tend to exempt themselves too often from performing their part in arrangements requisite for social life and welfare.

Another bias with special pertinence to our discussion manifests itself when people make decisions involving intertemporal choice. As David Hume once noted, ${ }^{60}$ when we express a preference or form an intention as to a future course of action -e.g. to go jogging tomorrow morning, go on a diet, or break a bad habit 61 — temptations pulling in the opposite direction may become harder to resist as the time for the intended action approaches, and we sometimes find ourselves departing from what we earlier held to be, and what may indeed be, optimal action. Modern experimental work has confirmed the existence of this effect and explained it as part of a common bias that behavioral scientists call myopic or hyperbolic discounting: in simple words, a tendency to overvalue immediate gains or imminent gratifications at the expense of long-term rewards. ${ }^{62}$ The bearing

60 Hume, supra note 57 , p. 536.

61 The examples are mine.

62 See, e.g., Ainslie, George, "Specious Reward: A Behavioral Theory of Impulsiveness and Impulse Control", Psychological Bulletin, vol. 82, 1975, pp. 463-96; Solnick, Jay H. et al., "An Experimental Analysis of Impulsivity and Impulse Control in Humans", Learning and Motivation, vol. 11, 1980, pp. 61-77; Ainslie, George and Haendel, Varda, "The Motives of the Will", in Gottheil, Edward et al. (eds.), Etiologic Aspects of Alcohol and Drug Abuse, Springfield, IL, Charles C Thomas, 1983, pp. 119-40; Millar, Andrew and Navarick, Douglas J., "Self-Control and Choice in Humans: Effects of Video Game Playing as a Positive Reinforcer", Learning and Motivation, vol. 15, 1984, pp. 203-18; Herrnstein, Richard J., "Rational Choice Theory: Necessary but Not Sufficient", American Psychologist, vol. 45, 1990, 
of this bias on our question hardly needs to be explained: legal rules are typically designed and applied in a prospective manner with the aim of forming social arrangements sustainable through time and in the face of impulsive tugs in human decision-making. This aim, however, is not likely to be duly reflected in an assessment of law-following values made by a subject in his daily setting of operation under the law. For, when confronted with the personal inconvenience involved in following a rule and with concrete and immediate stimuli pulling in the opposite direction, he is prone to be led by a myopic bias to give too little weight to the long-term advantages of following the rule.

We are now in a position to consider how situational biases of the type described above bear on the question of content-independence. It is primarily such biases, and their frequent presence in subjects' decision-making environment, that make it desirable for subjects to adopt the attitude of treating legal requirements as strongly, rather than weakly, content-independent reasons for action. ${ }^{63}$ A subject (call him subject 1) who operates in accordance with the

pp. 356-67; Winston, Gordon C. and Woodbury, Richard G., "Myopic Discounting: Empirical Evidence", in Kaish, Stanley and Gilad, Benjamin (eds.), Handbook of Behavioral Economics, Greenwich, CT, JAI Press, 1991, vol. 2B, p. 325; Kirby, Kris N. and Herrnstein, Richard J., "Preference Reversals Due to Myopic Discounting of Delayed Reward", Psychological Science, vol. 6, 1995, pp. 83-9; Kirby, Kris N., "Bidding on the Future: Evidence Against Normative Discounting of Delayed Rewards", Journal of Experimental Psychology: General, vol. 126, 1997, pp. 54-70.

63 It might be a limitation of my analysis in this Section that it focuses on the decision-making environment of private actors, rather than judges and other law-applying officials. Even if so, it is important not to overstate the extent of this limitation. Although some of the situational biases discussed above do not paradigmatically feature in the decision-making environment of law-applying officials, other situational biases and fallibilities do. See, e.g., Schauer, Frederick, "Rules and the Rule of Law", Harvard Journal of Law \& Public Policy, vol. 14, 1991, pp. 645-94, at pp. 679-81, Schauer, Frederick, Playing by the Rules, Oxford, Clarendon Press, 1991, pp. 149-55, 158-62, 229-33, where Schauer refers to the fallibility that characterizes some official decision-making environments in his explanation of the benefits of rule-based decision-making. He grounds the principal justification for reliance on rules in "decisional modesty" and the need to allocate decisional power between different decision-making environments according to their relative reliability or fallibility. My arguments are consistent with his position. 
weak notion of content-independence regards himself as having a reason to comply with law only if and insofar as he recognizes that an act of compliance is justified by substantive considerations applicable to his situation. As we have seen, however, when situated in his daily environment of activity under the law, his perception of such considerations is likely to be tainted by biases towards non-compliance. By contrast, a subject (call him subject 2) whose mode of practical reasoning accords with the strong notion of content-independence, regards law as providing him with reasons for action independently of his situational assessments of substantive considerations for compliance. Precisely because law-given reasons enjoy this type of independence in his practical reasoning, they can exert their influence in the face of situational biases and effectively counteract them. Hence, subject 2 is, ceteris paribus, less likely to commit practical errors than subject 1 . This, then, is a good reason, grounded in substantive considerations, to adopt the normative attitude of subject 2, rather than subject 1 -it is a weakly content-independent reason to adopt the attitude of treating legal requirements as strongly content-independent reasons. ${ }^{64}$

64 I said that the reason is a weakly content-independent reason, but it is perhaps more accurate to say that its content-independence, in addition to being weak, is no more than relative. For my argument proceeded, and depends for its plausibility, on an assumption that the relevant lawmaking institutions are reasonably just and competent, which, in turn, suggests that their enactments are likely to have (even if not always necessarily have) acceptable (even if not optimal) content.

I take myself to have shown in my earlier arguments (see particularly text accompanying nn. 31-38) that the above statement is internally coherent: i.e. that the former reason's being weakly content-independent does not turn the latter reason into a weakly content-independent reason as well. There are crucial differences between an actor who treats law as a provider of weakly content-independent reasons simpliciter and an actor who (for weakly content-independent reasons) adopts the attitude of treating law as a strongly content-independent reason for action. Two notable manifestations of the difference, which emerge from the foregoing discussion, are, first, in the modes of deliberation respectively used by these actors, and, second, the lack of extensional equivalence in the outcomes produced by their respective attitudes. First, at the deliberative level, since the first actor does not regard law itself as a reason for action, he approaches legal requirements by examining whether, and to what extent, compliance in the particular case at hand 
NOAM GUR

\section{CONCLUSiON}

Typical reactions to the idea of content-independent reasons range from unhesitant approval to outright dismissal; some think it illuminatingly captures a central property of law's normativity and authoritative nature, whereas others find it impossible to understand how mere artifacts of the human will can turn something into a reason independently of its substance and value. In this paper, I have suggested that this disparity of reactions results from insufficient attention to the relevance of three distinctions. The first distinction is between two different senses of content-independence, which I referred to as weak and strong content-independence. Weakly content-independent reasons are reasons that do not depend on the nature and merit of the action that law requires. Strongly content-independent reasons are reasons that do not depend on the nature and merit of the action law requires or on any other substantive law-following values (e.g. values associated with social coordination, order and stability, or fair play considerations). The latter rendering implies that the mere fact that law requires an action must itself count in the practical reasoning of its subjects.

In light of this distinction, it became transparent that what initially appeared to be a general objection against content-independence is in fact an objection against only one sense of content-independence, i.e. the strong sense. The weak sense, on the other hand, does not seem to impli-

would serve any desirable substantive goals (e.g. "this requirement is meant to facilitate coordination; but there is no one around; so by complying I would be "coordinating' with no one ..."). In contrast, the second actor treats legal requirements themselves as reasons for action, his inclination to comply with law is not contingent on situational assessments of the applicability of law-following values (though may occasionally be overridden by sufficiently compelling and clear reasons to the contrary). Second, the two attitudes are not extensionally equivalent in terms of the outcomes they produce; there are cases in which they diverge. Take again the deserted traffic light example discussed above; in this situation a correct assessment of the balance of reasons for action (including law-following values) as applicable to the case at hand recommends running the red light, but an actor who treats legal requirements themselves as reasons may well stop. 
cate any contentious or problematic claims. I therefore turned to consider the strong sense of content-independent reasons. At this point, a second distinction became relevant: namely, a distinction between evaluative statements about reasons (evaluating what reasons people have from a normative perspective unbounded by the internal assumptions of the legal practice) and descriptive statements about reasons (describing the reasons that characteristically figure in the practical deliberation of participants in the legal practice). From the former, evaluative perspective, strong content-independence, with its suggestion that reasons can come into existence through the mere say-so of a human agent, appeared no more plausible than a belief in the power of spells. From this perspective, the only type of content-independence that can sensibly be spoken of is the weak type. However, when we descriptively examined the way participants in the legal practice typically treat its requirements, strong content-independence appeared to have some explanatory force after all, though it had to be qualified by a third distinction: namely, a distinction between reasons for action and reasons for adopting certain attitudes. Thus, I have argued that although law-following values are part of what brings subjects to adopt and maintain the general attitude they normally have towards law -i.e. their law-abiding disposition, the attitude of treating legal requirements as reasons for action- this attitude makes its force felt in their action-specific deliberation independently of whether law-following values apply to the particular situation they face. In other words, law seems to typically operate in the practical reasoning of its subjects as a strongly content-independent reason for action, though subjects adopt and maintain the attitude of treating law that way due to reasons that are not content-independent in the strong sense.

Finally, I have argued that despite the observed discrepancy between the evaluatively sound type of content-independence and the descriptively correct type of content-inde- 
pendence, the two are nonetheless interconnected by a deeper rationale. That is, even though strongly content-independent reasons do not exist in the evaluative sense, there is an evaluative consideration which makes it desirable that, in our practical operation as subjects of the law, we proceed on an assumption or operate with an attitude which involves treating legal requirements as strongly content-independent reasons. Put in its most general form, the consideration is that by thus treating the requirements of a (reasonably just) legal system, we would be more likely to conform to substantive reasons that apply to us in legally regulated spheres of activity. The fundamental reason for this, I have argued, lies not so much with expertise or specialized knowledge that our lawmakers might possess, as with certain situational biases and fallibilities to which we are commonly susceptible in our settings of operation under the law. I have demonstrated that due to certain stimuli characteristically present in the decision-making environment of law's subjects, a bare assessment of law-following values carried out in that environment is likely to be tainted by biases leading one to discount or underestimate the weight of applicable law-following values. This observation made it clear why it is desirable that, in our usual operation as subjects of the law, we treat its directives as strongly content-independent reasons: only if we treat legal directives in this way can their normative force feed into our decisions without first being mediated by our situational judgment and watered down by the biases implicated in that judgment. Only this way, therefore, can law adequately counteract situational biases and fallibilities, and optimally fulfill its function as a normative guide to right action. 